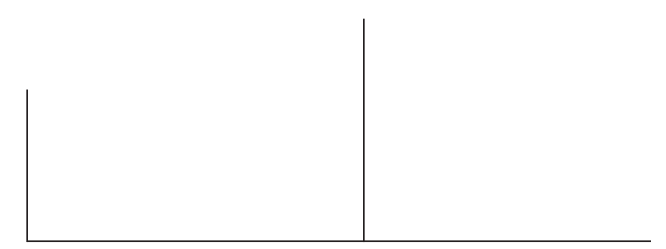

Rev. Latinoam. Psicopat. Fund., IV, 1, 106-124

\title{
A angústia e o sintoma na clínica psicanalítica
}

\author{
Tania Coelho dos Santos
}

\begin{abstract}
O sujeito sobre o qual a psicanálise opera é o sujeito da ciência. O inconsciente não é o que escapa à ciência e sim um dos efeitos de retorno dessa exclusão. O sintoma histérico foi um desses efeitos de retorno da foraclusão do nome-do-pai pelo discurso da ciência ou de sua redução à função do pai de família e às autoridade educativas e sociais. Hoje, vemo-nos confrontados com novos sintomas que parecem ter origem no esvaziamento progressivo da função paterna, e nos obrigam a ressituar a transmissão da castração para além do pai. A inexistência da relação sexual, ou a divisão do objeto mulher/mãe é uma outra vertente da castração que nos permite enfocar a estrutura do sintoma na atualidade.
\end{abstract}

Palavras-chave: Angústia, sintoma, função paterna, objeto $a$, castração 


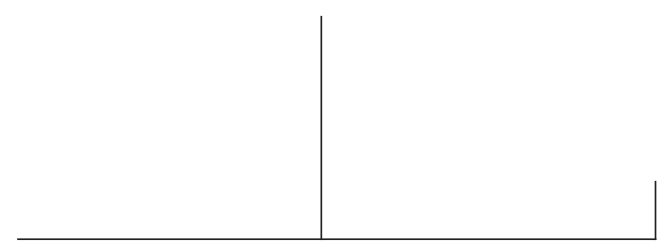

De que desejo do Outro a angústia é o sinal

A angústia é o afeto (Affekt) por excelência na clínica psicanalítica. De acordo com Freud, é a matriz de todos os afetos e o sinal (Angstbereishaft) que apela para o recalque. Para Lacan, é o único afeto que não engana: é o sinal da divisão do sujeito entre o gozo e o desejo. $\mathrm{O}$ que divide o sujeito, segundo Lacan, é o significante recebido do Outro de quem o sujeito depende absolutamente para conhecer o quer que seja acerca de sua necessidade. A demanda endereçada ao Outro retorna ao sujeito como desejo alienado, interpretado pelo desejo do Outro. O significante, essa marca do desejo do Outro, impõe ao corpo uma exigência de trabalho: a de só poder reencontrar o gozo recorrendo novamente ao campo do Outro.

Freud surpreendeu-se com a descoberta de uma estrutura inconsciente subjacente ao sintoma - a primeira mentira histérica - na qual a causa do desejo sexual é atribuída ao pai. E o que é o inconsciente senão o campo onde se elabora a fantasia? Somente por meio dela - na medida em que se serve dos significantes do Outro, da linguagem e da cultura - se pode sustentar a via do desejo no laço social. Esse último é, como outras formações do inconsciente, uma formação de compromisso entre o objeto perdido da pulsão e os significantes do Outro. Logo, o laço social só vem a se constituir como efeito da separação que a fantasia introduz entre o gozo e o corpo. Por meio da fantasia, o gozo que é efeito da privação do sentido, conseqüência da dependência do homem do campo do significante, tem de reacionar esse circuito, reencontrar o campo do Outro, para efetivar a única realidade possível para os seres de linguagem, a realidade psíquica ou o laço com o objeto. A fantasia inconsciente é esse operador estrutural necessário ao reencontro do objeto ou, dizendo de outro modo, à construção de um sintoma como uma modalidade de laço com o objeto. Incluímos na categoria de sintoma todo laço social, na medida em que implica um discurso e, portanto, a divisão do sujeito. Freqüentemente, esse laço é insuficiente para regular o acesso ao gozo para um sujeito e lhe é preciso inventar outra coisa. Angústia é o nome desse excesso, um gozo deslocalizado, cujo objeto não se apresenta nas vias da interpretação, da máscara, do engano, do sintoma que são as vias do desejo. 


\section{O pai em Freud e em Lacan}

Passamos a introduzir nossa discussão acerca de por que o desejo do pai é a causa do desejo para Freud e para Lacan. Há uma relação de estrutura entre a função do pai em Freud no complexo de Édipo e sua teoria da castração. Lacan (1969/ 1970), diferentemente de Freud, não vincula a castração tão estreitamente ao Édipo, preferindo ancorá-la nos efeitos da linguagem sobre o vivo (Coelho dos Santos, 1999a).

Freud (1912) atribui o mecanismo psíquico do recalque à função do pai. O pai é o agente da castração, isto é, a identificação com o pai mantém o sujeito na via do desejo afastando-o da atração pelo objeto incestuoso. O pai faz a lei do que se deve desejar, isto é, outra coisa que não a mãe. Por essa razão o desejo primordial é parricida. O pai é aquele que se supõe ter acesso a um gozo do qual priva os filhos. O pai, em sua função simbólica de agente da castração é necessariamente um pai morto. Como se vê, se o desejo é incestuoso, o gozo do objeto desse desejo não é compatível com o vivo. O pai será, por essa razão, o suporte dos ideais. Será lembrado como "o ao menos um" que, como exceção à castração, orienta o gozo na direção do gozo fálico, do gozo útil, promovendo as virtudes vitorianas da renúncia pulsional. O mal-estar na civilização explica-se pelos efeitos de renúncia ao gozo em consequiência da identificação com a lei do desejo do pai (Coelho dos Santos, 2000).

Lacan (1966) elevou a função do pai à de operador estrutural da constituição do sujeito enfatizando sua dimensão de significante da falta de gozo. Elevando o pai a uma metáfora da falta de gozo, Lacan promoveu também, ainda que paradoxalmente, a percepção de que o pai não passa de um semblante, um nome qualquer do que falta para que o gozo seja completo (Coelho dos Santos, 1999a).

Esse passo formal abre a possibilidade de pensar a clínica freudiana como referida a um tempo, a modernidade, em que o pai funciona como semblante da falta de gozo e que as neuroses histéricas e obsessivas dão testemunho de uma relação com o superego paterno. A formalização por Lacan da função do pai freudiano permitiu ver mais claramente como se distribuíam as estruturas - neurose, psicose, perversão - em torno da primazia do Nome-do-pai. Entretanto, o avanço do discurso da ciência e a difusão da psicanálise contribuíram para aprofundar o declínio do pai como metáfora da falta de gozo. A contemporaneidade faz com que nos defrontemos com uma nova clínica. Proliferam casos de difícil classificação, que nos incitam a repensar as fronteiras entre neurose e psicose (Coelho dos Santos, 1998).

Na modernidade, em consequiência do advento do discurso da ciência, o Nomedo-pai deixou de ser um operador estrutural visível da ordem simbólica. Na nova ordem, em que todos os homens se equivalem, o Nome-do-pai deveio quase um 


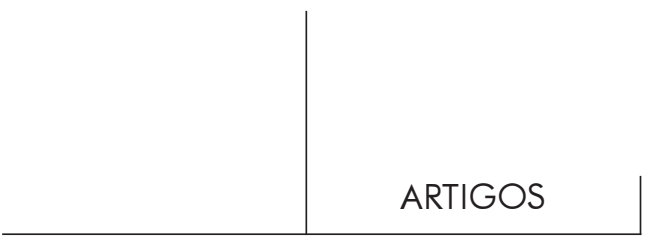

resíduo. Sua função limitou-se, principalmente, à esfera da família e a alguns outros papéis sociais como, por exemplo, o do educador.

Freud conclui que a angústia é o sinal no psiquismo do retorno do recalcado. Ele a diferencia das formas automáticas de angústia que denotam uma ausência de memória de experiências anteriores (Coelho dos Santos, 1994). A função do Nomedo-pai é o que possibilita inscrever no psiquismo uma explicação para a falta de gozo: o pai é o agente mítico da castração. O declínio da função paterna nos confronta com formas de angústia automáticas, afetação direta pelo real da falta de gozo, sem a mediação do significante do Nome-do-pai. Sem a proteção do imperativo paterno da renúncia à satisfação pulsional, o sujeito na contemporaneidade confronta-se, sem disfarce, com uma falta em gozar que não tem nome. Por essa razão, diante da falta de gozo, o sujeito é convocado a produzir uma resposta nova acerca do que falta para o Outro ser completo. Esse passo é absolutamente necessário para a constituição subjetiva, pois o sujeito hoje se arrisca a se deixar aspirar por esse vazio, cedendo à tentação de oferecer-se como objeto do gozo do Outro. É o que se verifica quando é preciso servir-se do abuso de drogas, do endividamento nos cartões de crédito, do consumismo desenfreado, da privação ou do excesso de comida ou, paradoxalmente, da adesão viciosa ao trabalho, para nomear aquilo que falta ao Outro, justamente, porque não se encontra mais o apoio no Nome-do-pai. Para compreender esse ponto é preciso circunscrever como foi que o Nome-do-pai veio a ser identificado com a causa do desejo.

\section{O regime histórico do ascenso do Nome-do-pai}

$\mathrm{O}$ advento do inconsciente aflora num contexto cultural marcado pela foraclusão de Deus no mundo. Após a queda do Antigo regime, o fim das monarquias antecede o nascimento do Estado moderno e a emergência de uma nova configuração leiga de valores (Dumont, 1992). Muito embora Marx (1844) considere que a base filosófico-moral do Estado moderno seja cristã, seu nascimento é, de acordo com Dumont (1992), fruto da emancipação do poder da Igreja e da separação dos domínios econômico, social e político com relação à religião.

O declínio do poder de agregação simbólico da religião é correlativo ao esvaziamento da dimensão do mito. Isso é o que nos autoriza a falar em declínio da função paterna. Essa função correlaciona-se com a de representante de Deus no mundo. O nascimento do discurso da ciência advoga para o pensamento o poder de determinação outrora atribuído a Deus e seus representantes. O discurso da ciência contribuiu para esvaziar os sentidos coletivos nascidos e conservados pelas práticas rituais que consolidavam os laços sociais e a relação com o próprio corpo. No lugar da autoridade religiosa, o direito à igualdade e à liberdade fomenta o indi- 


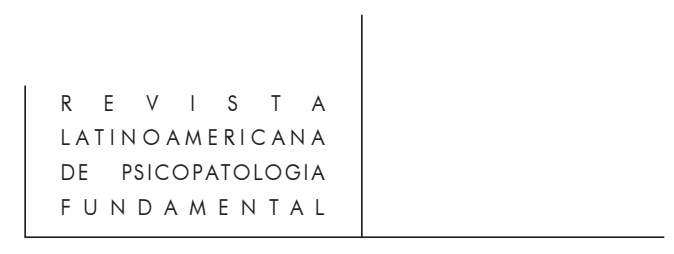

vidualismo e a descrença próprios à razão em detrimento do sentido fundado na fé. Sem o apoio na autoridade religiosa, a função do pai de família se esvazia da força de mandado divino que antes nela se investia e sua palavra já não pode transmitir a crença e a tradição, isto é, o sentido.

A época vitoriana viu florescer essa nova espécie de religião que são as superstições, crenças e mitos individuais do neurótico obsessivo como observou Lacan (1953). A experiência mística, por sua vez, deu lugar à conversão histérica.

Freud (1933) não hesitou em alinhar a psicanálise na vertente da Weltanschauung científica. A descoberta do inconsciente, em que pese o esforço freudiano em adequá-la ao ideal da ciência, representou uma séria interrogação a essa pretensão. Lacan (1966), diferentemente de Freud, considera que a psicanálise opera sobre o sujeito da ciência para reintroduzir o Nome-do-pai na consideração científica. Por essa razão, Lacan (1969/70) não cessou de interrogar-se sobre o desejo de Freud, acreditando que é preciso circunscrevê-lo historicamente ao advento do discurso da ciência moderna. Isso foi necessário para ir além de Freud e ressituar a psicanálise no quadro da ciência contemporânea. Passamos a delinear as relações de Freud com o advento da ciência na modernidade e o passo de Lacan que redesenhou essa relação, introduzindo - para além do pai - a vertente feminina da causa do desejo.

\section{Do Nome-do-pai ao objeto $a$ : duas vertentes do laço entre o desejo e o gozo}

A clínica freudiana, segundo Lacan, apontou uma diferença essencial entre a constituição subjetiva do neurótico e do psicótico. O sujeito, mergulhado originalmente na relação dual ou narcísica com a mãe, fica identificado ao corpo próprio como objeto que supre a falta materna. O pai interpõe-se entre mãe e filho e funciona como agente da castração, interdita o incesto ou a coincidência entre o corpo e o gozo. A marca da intervenção paterna é a identificação ao desejo do Outro paterno e constitui o sujeito dividido entre uma dupla injunção: "você não deve ser igual ao seu pai" e "você deve ser igual ao seu pai". Isso aponta precisamente o que o sujeito deve desejar, uma mulher, à condição de que seja outra, não a mãe. O laço sintomático com esse objeto - uma mulher - como a parceira no sintoma, orienta o desejo sexual nascido da dívida com o desejo do pai. O pai no mito freudiano de Édipo transmite a castração sexual, ou seja, a marca do desejo como desejo do Outro.

Lacan elevou o pai do mito freudiano à dimensão de uma metáfora da causa do desejo. Para tanto, formalizou uma oposição - que em Freud não é tão nítida entre os mecanismos psíquicos da neurose e da psicose. Lacan introduziu entre 


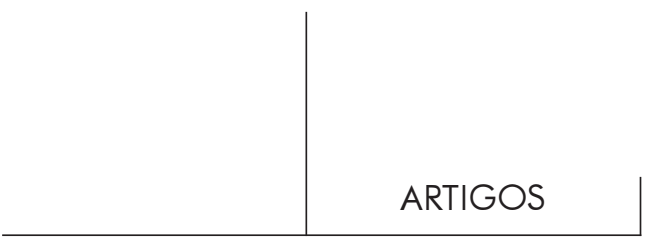

eles uma referência comum, o Nome-do-pai (Coelho dos Santos, 1999a). O nome não se reduz à pessoa do pai, é antes um efeito da linguagem. A posição do sujeito neurótico se produz por meio de uma afirmação (Bejahung) do valor do Nome-dopai como metáfora do desejo materno. A posição do sujeito psicótico resulta de uma foraclusão (Verwerfung), isto é, de uma não aceitação primordial do valor metafórico do Nome-do-pai. Nesse período da teorização de Lacan, o exercício da função paterna apresenta-se estreitamente associado ao lugar ocupado pelo pai de família. Ao pai de família cabe funcionar como agente da castração, privando a mãe da criança - como objeto do seu desejo - e apresentando-se como aquele que tem o falo e que pode dá-lo a ela. Essa ênfase no pai de família desaparece quando Lacan declara que nunca falou do pai senão como metáfora. É ao significante, Outro generalizado da linguagem, que a castração será atribuída. A introdução do significante é um fato de estrutura, logo tem valor para todos, neuróticos ou psicóticos. Atribuir a castração ao significante redimensiona de um modo inédito a relação do desejo com a lei. O objeto do desejo não é aquilo que o pai proíbe como queria Freud. A mãe não é o objeto do gozo incestuoso. Em consequiência do primado da linguagem sobre o complexo de Édipo, o objeto é desde sempre um objeto perdido. Também não cabe ao pai de família privar a mãe do gozo do corpo da criança como Lacan, ele próprio, pretendeu num tempo anterior de sua teorização. O mito edipiano não passa de uma conseqüência imaginária, uma fantasia acerca da origem da castração. Do mesmo modo, Lacan questiona o mito inventado por Freud em "Totem e tabu" acerca do assassinato do pai primordial como origem da lei, do desejo e da castração. Declara que esse suposto pai real não passa de uma construção que sustenta a fantasia de que o pai edipiano é o agente da castração. A lei não tem fundamento na culpa, nem no crime de assassinato contra o pai, tampouco na sujeição à proibição paterna. A lei é a lei, seu fundamento será tomado a partir de um impossível lógico, o objeto causa do desejo ou, melhor dizendo, a única prova da alteridade do Outro. À generalização do Outro corresponde a foraclusão generalizada do Nome-do-pai. Vamos desenvolver esse ponto fazendo um contraponto entre o Outro não barrado, Outro consistente do pai no mito freudiano de Édipo e o Outro que não existe, introduzido por Lacan pelas vertentes da sexuação presididas por uma outra lógica: a de que "não há relação sexual".

O que o significante transmite é a castração, a falta de um objeto. Há uma outra via de transmissão da castração e que vai além do Nome-do-pai. Quando, em RSI (1975/76), Lacan assume que um homem pai não tem direito ao respeito nem ao amor se esse amor não for perversamente orientado para uma mulher, apresenta a mulher como objeto $a$, sintoma do homem. Entretanto, essa relação não é recíproca, isto é, o homem não é o parceiro-sintoma da mulher e sim a criança. A transmissão da castração obedece, nessa nova formulação, uma outra lógica, pois não procede do pai, como o Outro consistente, portador do falo. A castração é o 


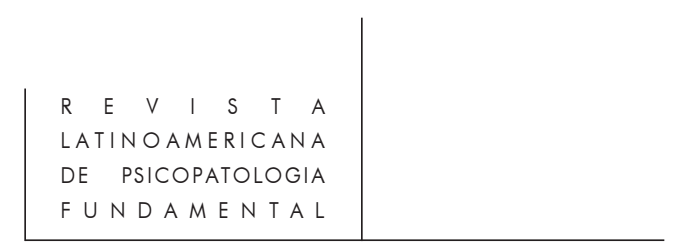

efeito de que mulher é um Outro barrado, dividido entre a mulher - sintoma do homem - e a mãe cujo objeto $a$ é a criança. Essa nova fórmula remete a divisão do sujeito à inexistência da relação sexual.

A relação sexual no âmbito do complexo de Édipo é incestuosa e por isso é proibida. O desejo incestuoso alimenta-se da crença da qual o pai é o agente da castração. A contrapartida do desejo incestuoso é o ódio parricida. Ambos alimentam uma vontade de gozo que empurra para o desafio e a transgressão. O gozo na vertente edípica promete o sujeito à morte. É o que se vê no mito de "Totem e tabu". Pai gozador, pai morto. O gozo é não apenas proibido, mas também impossível, incompatível com tudo que é vivo (Coelho dos Santos, 1999b).

A castração do complexo é diferente porque ela é o efeito de que só haja um órgão sexual para ambos os sexos: o falo. Logo, não há Outro sexo. A conseqüência psíquica será a inexistência da relação sexual. Não há relação sexual porque o Outro não existe. O gozo, mais que proibido, mais que incompatível com a vida, é inconciliável com o sexo. O complexo de Édipo e o complexo de castração têm isso em comum: situam o gozo como limitado pela castração. Essa deficiência pode ser deslocada? Como se poderia abordar o gozo sem limitá-lo pela proibição, pela impossibilidade ou pela inexistência de parceiro?

O progresso do ensino de Lacan (1972/73) aprofunda uma dicotomia na vertente do feminino. A mulher é não-toda assujeitada à vertente fálica da castração. Na vertente da sexuação fálica o gozo da mulher estrutura-se em torno da reivindicação do falo. O gozo da mulher reparte-se entre a vertente do falo e outra, para além dele. Na vertente fálica da sexuação, se "todo homem é assujeitado à castração" é porque o que funda o homem como universal é a exceção: há "ao menos um" que não está submetido à função fálica. Nessa vertente, o gozo fica aprisionado entre um gozo reduzido ao possível e um gozo que seria "todo" se não fosse impossível.

Na outra vertente lógica, podemos partir da necessidade do assujeitamento à castração. A castração, que é efeito da linguagem e não do Édipo, é necessária, não conhece nenhuma exceção. Nessa outra vertente, a ausência da relação sexual não se ordena em torno do falo, significante da diferença sexual, e sim do resto da sexuação fálica, o objeto $a$. O objeto $a$ é o índice de um outro gozo, um gozo a mais, um gozo suplementar à ausência da relação sexual. A castração para além do Édipo prescinde do falo como garantia da universalidade. Sem o falo, a ausência da relação sexual é desmascarada. É preciso que seja introduzido um objeto suplementar, por essa razão não-todo assujeitado à castração, para que possa haver laço social. Podemos pensar na condição do gozo para além do falo, como um objeto contingente, novo, inventado para fazer suplência da inexistência da relação sexual.

A diferença entre esses dois operadores estruturais da constituição do sujeito, o falo e o objeto $a$, é essencial para definir como se estrutura o sintoma na con- 


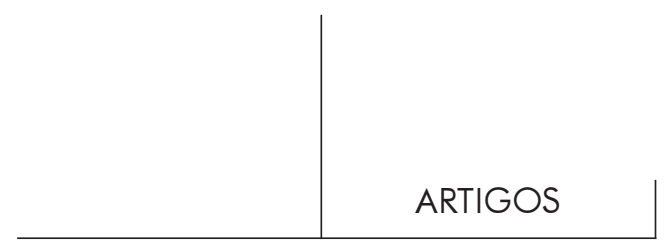

temporaneidade. A vertente fálica da sexuação apreende o objeto como incestuoso. O objeto $a$ de Lacan não é o objeto incestuoso, nem a Coisa (das Ding) à qual só se tem acesso pelo heroismo, pela transgressão ou pela tragédia. A mulher é nãotoda assujeitada à castração quer dizer que há um gozo que é contingente, que não se regula pela sexuação fálica. Para além do falo, o acesso ao gozo não implica a transgressão e sim a causa do desejo, o que pode limitar-se a, por exemplo, uma "condição fetiche". Podemos tomar como índice desse gozo o desejo de um homem por uma mulher. Do lado da mulher há um gozo do qual ela não é sujeito, ela não o reivindica, uma vez que ela seja o objeto $a$ para o desejo do Outro. O objeto $a$ não é o índice de um gozo perverso com a fantasia. É uma suplência da relação sexual que não há. Essa diferença define suas maneiras de conceber a fantasia: a freudiana e a lacaniana.

O encontro com o desejo do Outro, com a falta no Outro correlaciona-se com a antecipação do Outro que não há. Nesse ponto, a angústia é o sinal da perda do sentido, de um confronto com a ausência da relação sexual. Na vertente da sexuação fálica, toda angústia é angústia de castração, pois antecipa o encontro com o Outro sexo que não existe porque para ambos só há o falo. Para além do falo a angústia deve dar lugar ao desejo de um objeto que seja outro, cuja estrutura seja não-toda submetida à castração. A angústia é o sinal da destituição subjetiva, ou seja, o sujeito aí é um objeto causa do desejo do Outro. A angústia antecipa-se ao sujeito, neste ponto em que ele não é ainda. O tempo da angústia é o tempo da muda. O tempo da angústia requer alguma coisa para além da castração. Lá onde isso estava o sujeito, o desejo deve advir. Entre o gozo e o desejo, a angústia é geralmente o sinal da exigência de produzir uma suplência, um objeto para a pulsão. Anuncia que o sujeito deverá reencontrar-se lá onde isso estava e ele não sabia.

\section{Da foraclusão do Nome-do-pai à foraclusão generalizada ou à generalização do Nome-do-pai}

Contemporaneamente, o "Outro não existe"? A transmissão da castração desliga-se da transmissão de sistemas coletivos de ideais. O ascenso do Nome-do-pai é correlativo da foraclusão de Deus do mundo. É o nascimento da religião, nostalgia do amor do pai. Aquilo que chamamos de declínio da função paterna deve ser correlacionado, num primeiro passo, à pluralização dos Nomes-do-Pai. Secundariamente, não seria o ascenso de uma nova abordagem da sexuação que toma por critério a relação ao sintoma ou ao objeto causa do desejo? O que entendemos por Outro não barrado seria uma Mulher que fosse toda. Esse Outro não barrado não é o Outro consistente da equação edípica pai privador/pai doador. Pelo contrário, muitos pais, contemporaneamente, desvencilham-se da sua função de privar a mãe do 


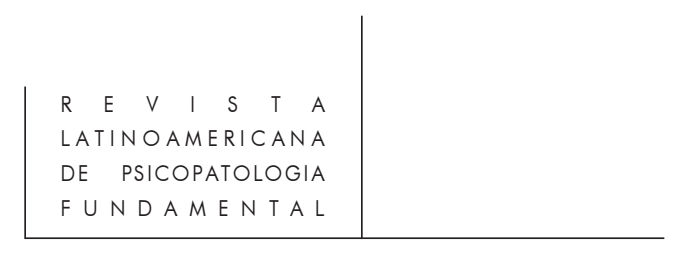

gozo da criança. O enfraquecimento do papel do pai de família freqüentemente limita a função paterna ao desejo de um homem por uma mulher, como o que a divide entre mulher e mãe. É a mulher e não o pai que sustenta, dessa forma, a função do Outro barrado. A primazia da função do pai já não é o modo soberano de organização da família e da transmissão do desejo como um saber sobre o que falta ao Outro. Se, como dizíamos, Freud pretende que é preciso tomar a via do Édipo para engajar o corpo na significação sexual, a redução do significante paterno ao desejo de um homem por uma mulher como única garantia da castração do sujeito, que efeitos determina sobre a posição subjetiva? Vivemos um ascenso da psicose generalizada? Ou será mais pertinente falar na expansão de uma espécie de "doença da mentalidade", isto é, de laços sintomáticos frouxos que deixam o sujeito mais exposto à invasão de um gozo deslocalizado, ao excesso de angústia e à necessidade de produzir suplências muitas vezes fora do discurso, fora do laço social.

Para situar esse ponto, passamos a fazer a diferença entre a foraclusão do Nome-do-pai (Verwerfung) da psicose no primeiro ensino de Lacan e a foraclusão generalizada que marca uma nova posição diante das relações entre o significante e o gozo. Desse modo, o que queremos situar é a tese de que a inconsistência do Outro é correlativa de uma generalização do Nome-do-pai, isto é, da dependência do sujeito do significante. Implica acrescentar que a pulsão deve passar necessariamente pelo Outro para "se fazer" objeto de uma satisfação passiva que vem do Outro. A passividade pulsional, como Freud estabeleceu bem, requer uma dose considerável de atividade. Isso posto, trata-se de esclarecer como pode se dar a produção de sintomas para além da função paterna no Édipo. Ou de como o significante da Mulher, como o Outro barrado, intervém para constituir um sintoma, um laço social, uma localização do gozo fora do Édipo.

À medida que a função significante encarnada nos representantes de Deus no mundo desaparece, paradoxalmente, ergue-se no mundo moderno o reino do Nome-do-pai. Segundo Laurent e Miller (1996/97), é o tempo da morte de Deus e da invenção da psicanálise. O reino do Nome-do-pai é o do significante da existência do Outro. É dessa crença no Outro, na existência e na consistência desse Outro que Freud dá testemunho em seu "Totem e tabu". O mito do assassinato do pai primevo é um recurso para explicar o nascimento do laço simbólico e social. Segundo Freud, o laço social se funda numa renúncia à satisfação pulsional porque o "pai morto mostrou-se mais poderoso do que vivo". O fundamento do superego como imperativo de renúncia ao gozo é um efeito de consistência do pai morto. O pai morto, guardião do gozo como impossível, é o operador da dominância do simbólico. O sujeito no simbólico é um sujeito barrado, morto, marcado pela metáfora paterna. A função metafórica requer que o gozo seja propriedade do pai como morto. 


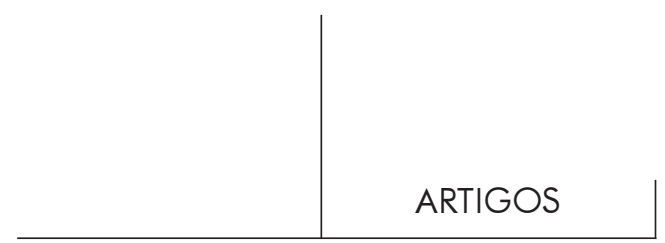

Quando generalizamos a foraclusão, apontamos para a inexistência da relação sexual ou, melhor dizendo, para a não coincidência entre o sintoma do homem e da mulher. Resta concluir que se generalizamos a foraclusão e a posição subjetiva na psicose, relativizamos a neurose e a significação fálica, mas, nesse passo, não nos desvencilhamos das consequiências psíquicas da diferença anatômica entre os sexos.

\section{Da histeria moderna à contemporânea: a angústia diante da falta de gozo sem o álibi do Nome-do-pai}

Depois de Lacan, aprendemos que o complexo de Édipo não explica a origem da castração. A falta de gozo é menos o efeito da proibição que o pai nos impõe, do que uma conseqüência direta da estrutura de linguagem. A falta de gozo não é a consequiência da restrição imposta à sexualidade pelos ideais paternos e sim a consequiência de que a pulsão tem relações de estrutura simultâneas com o simbólico e o real. Por essa razão, a satisfação esperada e a que é encontrada não poderão mesmo ser proporcionais. As novas formas de histeria, de sofrimento psíquico, são o efeito de um impasse (e não do mal-estar) na civilização diante da inexistência da completude, isto é, a inexistência de proporção entre o que se busca e o que se encontra.

Diferentemente das neuroses tradicionais não se pode mais atribuir ao pai a causa da falta de gozo. Diante dela não se pode mais apelar para seu nome, seja para combatê-lo, seja para reivindicá-lo. Falta esse poderoso álibi e só resta atribuir ou requerer de si próprio aquilo que falta para o gozo ser completo. Por essa razão, os novos quadros clínicos não se estruturam em função do que falta ao pai e sim do que falta ao próprio corpo e ao próprio eu. É assim que compreendemos a proliferação de quadros de depressão, autodesvalorização, síndromes do pânico, bulimia, anorexia, uso de drogas e insatisfação crônica com a forma do corpo que se reflete na busca compulsiva de cirurgias plásticas, dietas e ginásticas.

Precisamos aprofundar a discussão estrutural acerca das novas manifestações da angústia e sua dependência das novas configurações do saber científico, das novas formas de experiência do corpo e da sexualidade e principalmente dos destinos da clínica psicanalítica tendo em vista os efeitos da difusão da psicanálise.

\section{A real da ciência e o Outro que não existe: da angústia ao sintoma}

Há uma relação de estrutura entre a ciência e a subjetividade contemporânea. Permanecemos sob o mesmo eixo: o discurso da ciência foraclui o sujeito, o mito, a crença, o sentido. A psicanálise opera supondo que há um resto dessa operação: o Nome-do-pai. O sujeito sobre o qual a psicanálise opera é o sujeito da ciência. E 


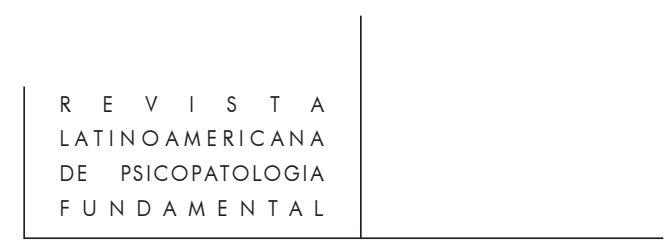

o que é a ciência moderna? É a ciência que supõe que há saber no real. Freud, segundo Laurent e Miller (1996/97) também supõe que "há saber no real". Por essa razão, o sujeito freudiano é, como Lacan veio a defini-lo, um "sujeito suposto saber". O nome do real freudiano é esse saber, isto é, o desejo inconsciente. A psicanálise freudiana como toda a ciência moderna decifra o saber suposto no real. Esse é o tempo de Freud e do nascimento da psicanálise, o tempo da primazia do simbólico e do efeito imaginário do complexo de Édipo. Nesse tempo, tanto as neuroses como as psicoses ordenavam-se em torno dessa fantasia coletiva, crença quase religiosa no amor do pai. O tempo de Freud é um tempo em que a existência do Outro, a fantasia acerca do Outro, funcionava como uma ilusão coletiva. Da modernidade à contemporaneidade avançamos desde a certeza da razão e da ilusão religiosa até a certeza localizada, isto é, certeza contraditória com outras tantas certezas e, por conseguinte, uma certeza que nos deixa numa incerteza relativa. O tempo de Lacan é o da inconsistência do Outro como uma fantasia coletiva, que ele termina por formalizar como a pluralização dos Nomes-do-Pai. O sujeito do tempo de Lacan não é um crente no Nome-do-pai, na tradição, na religião ou na ciência. Ele não pode ignorar que o Outro é ficção, um semblante, uma máscara.

Há, entretanto, um passo de Freud à Lacan. A ciência avança em seus recursos de formalização. Isso tem o efeito de aprofundar o vazio no real. Desse esvaziamento resulta que o real não pode ser decifrado porque não há saber no real. O que faz, então, a ciência contemporânea diante desse real esvaziado de saber. A ciência contemporânea intervém no real. A ciência hoje não decifra o real, ela o reinventa. Correlativamente, o sujeito como interpretação tende irreversivelmente a esvaziar-se. A intervenção do analista deve levar em conta o modo como o real se apresenta na clínica hoje.

No lugar da demanda de significação que, a propósito, inspirou a técnica freudiana da associação livre, temos o sujeito acéfalo, imerso no tempo real de um presente eterno. Ele se retrai ou age, consome ou se recusa a consumir, trabalha ou paralisa-se sempre compulsivamente. Deprimidos ou estressados, são novos os sintomas e as modalidades da angústia que confrontam os psicanalistas com a exigência de repensar o que é o fazer da psicanálise. O ato do analista, na contemporaneidade, poderá enfrentar a exigência de subverter essas configurações da subjetividade em impasse e fazer advir novos limites, novas fronteira entre o desejo e o gozo? O que deve ser o ato do analista, quando nos falta o fundamento da interpretação que é o Nome-do-pai no simbólico?

De acordo ainda com Laurent e Miller (1996/97), a época lacaniana da psicanálise é a dos movimentos acelerados, de desmaterialização vertiginosa em que o sentido do real tornou-se uma questão. Hoje há uma crise, um mal-estar quanto ao real, pois a imersão do sujeito contemporâneo nos semblantes é o efeito do declí- 


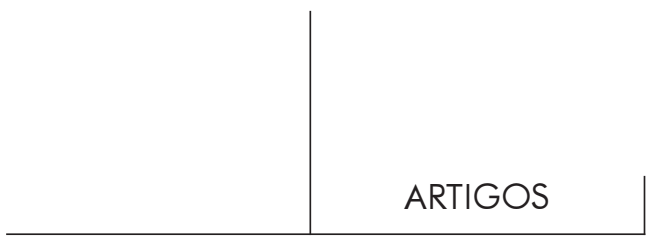

nio do ato de fé em Deus e o ascenso da demonstração científica. Quanto ao real, não temos mais que respostas contraditórias, inconsistentes e incertas. Contraditoriamente, a difusão do saber da ciência prolifera desatrelada da transmissão da castração. O saber da ciência difunde-se como um Outro não-barrado, desvencilhado da tradição de um coletivo ou da experiência de um sujeito particular, sem a marca da perda que sustenta a relação a um ideal.

Como testemunha Laurent e Miller (1996/67), o simbólico contemporâneo, isto é, a função do significante na modernidade, promoveu ao máximo um sujeito desassujeitado da tradição, da transmissão da castração. $\mathrm{O}$ efeito disso foi uma mudança profunda no campo da identificação, pois tudo que concerne ao sujeito e aos afetos está assujeitado ao imaginário e em continuidade com ele. A função simbólica, que depende da falta no Outro, da castração no Outro, já não atravessa as relações entre sujeitos supostos "todos livres e iguais". Quanto ao real, então, a verdade não tem mais estrutura de ficção. A ficção generalizou-se e submergiu à verdade que ela devia velar. A verdade prospera, está por todo lado, paradoxalmente, a céu aberto. Ao engano generalizado se opõem os novos sintomas como a depressão, a angústia, o pânico contemporâneos, que dão testemunha da relação a um real impossível de suportar.

Para finalizar esse trabalho, como uma marca de toda a nossa trajetória de pesquisa, queremos colocar em relevo as espécies do Outro que informam o sintoma. Se tomamos o Outro no âmbito da linguagem, da cultura, do laço social, é para valorizar a dimensão social do sintoma. Muito embora os sintoma contemporâneos evoquem o declínio da função paterna, no sentido do esvaziamento do laço social referido ao desejo do pai edípico, isso não quer dizer que não se estruturem a partir do Outro. A dimensão do Outro, necessariamente implicada no sintoma, não é contraditória com a inexistência do Outro. Uma clínica do real, da pulsão, não pode deixar de delimitá-lo precisamente a partir das identificações. Apesar da foraclusão de Deus, da universalização dos direitos do Homem, do feminismo, da difusão da psicanálise, ainda é preciso subjetivar-se tendo em conta a posição de objeto diante do desejo do Outro. A questão histérica - "o que é ser uma mulher" - e a posição psicótica de identificação a "ser uma mulher" demonstram que a castração, no sentido sexual, pode veicular-se pela via do objeto sem que o significante ou o pai edípico seja a agência mestra imprescindível para isso.

Podemos concluir que a função do pai dependeu um dia da família paternalista. Lacan pensava que as neuroses evoluiriam para um complexo caracterial por carência do Nome-do-pai. A liberação sexual, o feminismo, a suspeita generalizada contra toda autoridade desencadeou o lento enfraquecimento da diferença entre os sexos e as gerações. A homogeneização, a equalização, a liberalização dos costumes são alguns dos índices dessa carência. Essas mudanças aceleradas na cultura nos exigem trabalhar o conceito de identificação como relação ao Outro (Coelho 


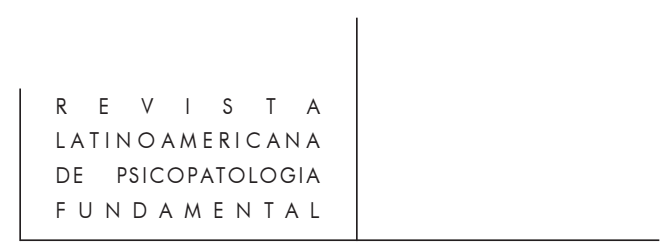

dos Santos, 1997). Como se pode constatar facilmente, há pelo menos dois Outros em Lacan. O Outro unitário e consistente $-A-$, que agora podemos situar como o que deriva dos mitos freudianos e que levou Lacan a soldar a primazia do simbólico à função do pai na família paternalista. E há, ainda, o Outro inconsistente que entendemos como uma nova versão do Outro faltante, $A$ barrado, desejante, passível de múltiplas leituras e que pode, no limite, reduzir-se a um significante. Nesse sentido, o Outro inconsistente não se apóia no pai edípico e sim nos comitês de ética, ou mesmo no confronto com a pluralização dos Nomes-do-pai.

Quanto ao Outro que não existe, pudemos desenvolver sua articulação com a mulher como "não toda", isto é, dividida entre mulher e mãe. A Outra face do Outro que não existe deve ser concebível a partir de tudo aquilo que se produz para fazê-lo existir, consistir, obturando a castração. Pretendemos, então, que o Outro inexistente remete a uma outra face do Outro contemporâneo, Outro não barrado, que comparece por meio do discurso da ciência encarnada no capitalismo, arregimentando um circuito em que a oferta precede a demanda e circula como puro imperativo de consumo. Exigência que deriva de um superego, parceiro da pulsão, que impele o sujeito a consumir-se junto com o objeto. A grande neurose contemporânea, como bem a definem Laurent e Miller (1996/97), funda-se no fato de que a inexistência do Outro lança o sujeito na caça ao mais-de-gozar. Efeito que não podemos desvencilhar da autonomia das leis de mercado, das leis da oferta e da procura, da mais-valia da mercadoria como objeto fetiche que se oferece como um valor puro, um imperativo de valor para todos, indiferente ao laço sintomático do sujeito a um objeto particular.

Lacan, em "Kant com Sade" (1966) já formalizava a homologia estrutural entre a moralidade kantiana e o imperativo do gozo sadeano. Lacan suspeita que sob a ética supostamente científica de Kant jaz uma exigência cadaverizante: a relação que ela prescreve a um objeto universal, de valor para todos (Gute), ao qual só acedemos às expensas do objeto patológico (Wöhl), aquele que justamente não goza de universalidade bastante para fazer a lei. Correlativamente, Lacan extrai de Sade uma máxima oculta - "tenho direito de gozar do seu corpo, pode me dizer qualquer um" - que veicula, ao avesso de uma ética universal, o mesmo imperativo superegóico de um gozo sem os freios da consideração pelo objeto particular. O superego como renúncia ao gozo de que fala Freud é efeito do imperativo categórico kantiano. Seu avesso, ou seu negativo, é a fantasia ou a perversão.

As patologias contemporâneas remetem ao estatuto do Outro dividido entre, por um lado, inconsistente ou plural e, por outro, inexistente ou sólido de uma consistência negativa: a recusa do objeto particular ou mais precisamente do contingente.

Nesse momento, queremos nos deter na seguinte questão proposta por Laurent e Miller (1996/97): o que é a identificação quando o "Outro não existe"? Freud, 


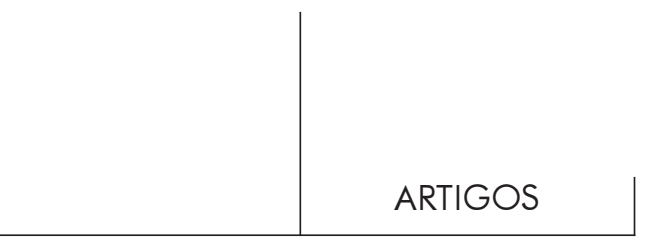

em "Psicologia de massas e análise do eu" distingue três identificações tal como se segue:

O que aprendemos dessas três fontes pode ser assim resumido: primeiro, a identificação constitui a forma original de laço emocional com um objeto; segundo, de maneira regressiva, ela se torna sucedâneo para uma vinculação de objeto libidinal, por assim dizer, por meio da introjeção do objeto no ego; e, terceiro, pode surgir com qualquer nova percepção de uma qualidade comum partilhada com alguma outra pessoa que não é objeto do instinto sexual. Quanto mais importante essa qualidade comum é, mais bem-sucedida pode tornar-se essa identificação parcial, podendo representar assim o início de um novo laço (Freud, 1921: 136).

Essa última identificação Freud esclarece que é uma identificação por meio do sintoma, sinal de um ponto de coincidência entre dois eus, sinal a ser mantido recalcado. O laço mútuo existente entre os membros de um grupo é da natureza de uma identificação desse tipo que, geralmente, reside numa importante qualidade comum: o laço com o líder. O laço originário com o objeto é, segundo me parece, o que mais apropriadamente descreve a palavra identificação: aquele em que não há distância entre o eu e o ideal ou, se preferirmos, entre o corpo e o significante. A regressão desse laço determina uma introjeção do objeto no eu que divide o sujeito e arrisca consumi-lo em auto-acusações, culpabilidade e angústia. A redução da distância entre corpo e gozo é a característica mais marcante dessa estrutura. Podemos verificar que essa patologia deriva da experiência de ser seu próprio algoz ou seu próprio ideal. É preciso que nos interroguemos, então, se podemos derivá-la da identificação a um "Outro que não existe".

Devemos, pois, situar as modalidades da identificação em Lacan e, para tanto, seguimos a exposição de Laurent e Miller (1996/97). O sujeito barrado de Lacan, sujeito marcado pelo traço unário da linguagem, dividido pelo significante, encontra o complemento de sua castração num primeiro nível, o do próprio significante, no Ideal do eu - I(A). Há, ainda, um outro modo de complemento do sujeito que tem uma afinidade com a recuperação da parte do corpo afetada pelo significante: o objeto $a$. Na concepção estrutural temos $I$ (significante por identificação) e $a$ (conexão fantasmática).

De acordo, uma vez mais, com Laurent e Miller (1996/97), o Nome-do-pai é a mesma coisa que o conceito de identificação $[I(A)]$ e o de fantasma [objeto $a$ ]. Um sujeito barrado é composto por suas metáforas subjetivas e pelo "objeto $a$ " de seus fantasmas. A partir do Seminário 17, Lacan situa o significante como o que constitui o gozo. S1 é uma nova versão do significante que não remete ao ideal do eu nem mesmo à referência ao Outro por meio de $I(A)$ e sim por meio de um outro significante: $S 2$. Na concepção estrutural, o traço unário do significante marca o sujeito com o traço do Outro $(A)$, identificação primeira ao ideal do eu. Com 


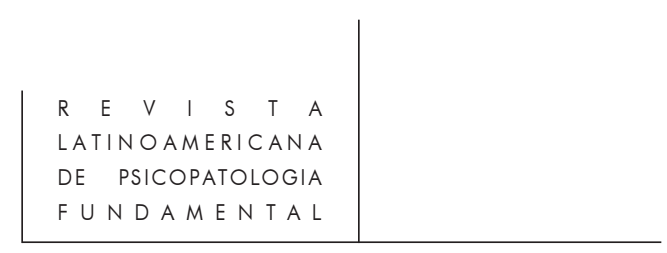

S1 é outra coisa, pois se funda no discurso do mestre. Ou seja, $S 1$ é histórico e relativo. Além disso, é homófono de essaim (edeuxsaim), soa como enxame, isto é, tende a pluralizar-se. O um é o um que funda e que se multiplica.

Há ainda outra vertente da identificação, a do fantasma, em que um termo como o objeto $a$, que não é um significante, pode tomar esse lugar e desempenhar o papel do significante mestre. Tomar a vertente do fantasma como uma modalidade de identificação representa reduzir o significante mestre a um lugar, o do agente do discurso: o significante em nome do qual eu falo. SI de Lacan é uma espécie de I ( A barrado).

A chave para compreender essa mudança na teoria da identificação de Lacan me parece ser a seguinte afirmação de Laurent e Miller (1996/97): a França e os EUA opõem dois tipos de identificação: vertical ao líder e horizontal ao par. Essa sentença nos remete à afirmação de Lacan (1938) a respeito da evolução da neurose histérica na direção de um complexo caracterial, efeito da separação entre as funções sublimatórias e repressivas antes reunidas sob o Nome-do-pai. A identificação ao par é ainda uma identificação ao sintoma. Sua construção tem, entretanto, uma estrutura diferente da identificação ao líder. Essa outra modalidade de laço, fantasmático, é, segundo Freud, o laço originário ao objeto, é o desejo de ser o objeto do Outro. Lacan rebatizou isso que Freud nomeou como a "identificação com base no laço oral" de desejo da mãe.

S1 é o significante mestre para os tempos de discussão, de sociedade deliberante, na medida em que não requer como complemento um ideal, mas somente um S2. O sujeito barrado é o significante mestre do discurso capitalista. Não há outro significante senão a vacuidade do sujeito, seu culto à autenticidade, ao desenvolvimento, lazer, auto-referência. A vacuidade do sujeito, nessa vertente da identificação a um $S 2$, impõe exigências superegóicas mais difíceis de suportar, pois: o dever de viver e de gozar se impõem com uma ferocidade especial. Resulta disso uma debilidade da identificação, isto é, do significante que engancharia o sujeito no Outro. Depois da sociedade de consumo, vivemos numa sociedade deliberativa, em que o discurso do Outro flutua. É a debilidade generalizada: o "Outro não existe". Os comitês de Ética são a expressão da comunidade dos débeis, isto é, dos desengrenados do discurso do Outro consistente que não há mais. Somos obrigados a conversar, avaliar, discutir, deliberar e jogar conversa fora. Tudo depende de como cada um interpreta seu sintoma. Em tempos em que os direitos individuais afrontam quaisquer objetivos coletivos é preciso levar em conta, estudar cuidadosamente, as ancoragens locais do gozo em oposição aos sistemas de ideais mais próprios a um Outro consistente.

Será que é possível estabelecer a estrutura do que podemos chamar de novos sintomas na contemporaneidade, se as tomamos como equivalentes às neuroses de caráter, isto é, às identificações ao desejo da mãe, ao Outro com base no laço oral? 


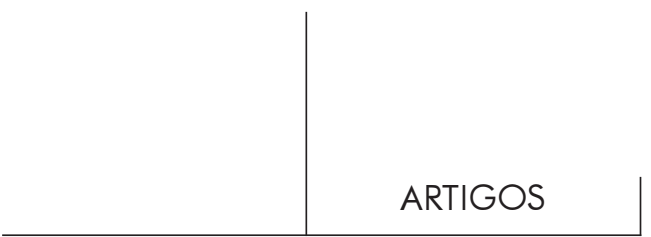

Podemos pensar, acompanhando Laurent e Miller (1996/97), que a estrutura do sintoma tem provavelmente a vivacidade das epidemias locais que testemunham ancoragens particulares do gozo. A identificação histérica, como se vê, depende de uma identificação anterior a um grupo forte. Logo, não se trata de um "Outro que não existe" e sim de um Outro inconsistente, isto é, de um Outro relativo ou plural. A identificação dominante é ainda a identificação histérica, que tanto se generaliza por contágio como requer um desejo ou um traço isolado ou até um líder. Essa tese, entretanto, é contraditória com a tese da dominância da identificação ao par.

Penso que a extração de um princípio rigoroso que permita distinguir um novo sintoma de um sintoma formado pela via do desejo histérico, implica deduzi-los da vertente identificatória do fantasma em que o objeto $a$ é o agente e toma o lugar do significante mestre. Para isso é preciso considerar que a subjetividade contemporânea resulta da absolutização dos direitos do sujeito, proprietário de seu corpo e isso exclui estar a serviço das ambições globais de uma coletividade. O superego freudiano remete às interdições, deveres, culpabilidade e outros tantos termos que refletem uma cultura que fez o Outro existir como sistema de ideais. O superego lacaniano dá testemunho de um novo tempo, um tempo em que o sujeito não deve nada senão ao seu direito ao gozo. O imperativo "Goza!", recalcado, velado, disfarçado na modernidade exibe-se sem disfarces, hoje, como o verdadeiro superego de nossa civilização. Entendo que temos uma nova maneira de fazer o Outro existir, absolutizando o direito ao gozo.

A hipótese de uma foraclusão generalizada correlaciona-se à constatação de que não há um Outro coletivo, universal, consistente o bastante para dar sustentação a um ideal do eu. À foraclusão generalizada coordena-se a tese da pluralização dos Nomes-do-pai, da relatividade do sintoma e das ancoragens locais do gozo. Se reduzimos a inexistência do Outro à pluralização dos Nomes-do-pai, não chegamos efetivamente a justificar nenhum salto qualitativo, nenhuma mudança essencial no modo como o sintoma é aparelhado. Trata-se, ainda, de uma conexão entre o significante e o gozo, por meio do Nome-do-pai, isto é, uma substituição metafórica, uma conversão histérica.

A vacuidade do sujeito no contemporâneo, para além da inconsistência, dá testemunho da inexistência do Outro. O sujeito esvaziado é o parceiro de um significante que impõe exigências superegóicas mais difíceis de suportar, pois: o dever de viver e de gozar se impõem com uma ferocidade especial. Acho que podemos esclarecer essa estrutura por meio da generalização da relação ao desejo materno que definimos como o ser que absorve é inteiramente absorvido e o complexo arcaico lhe responde no abraço materno" (Lacan, 1938: 26).

Preferimos concluir provisoriamente que o sintoma é um laço social que pode aparelhar o gozo sob a presidência de um Nome-do-pai ou sob o império do objeto a que não é um significante. No primeiro caso, a angústia é um sinal 


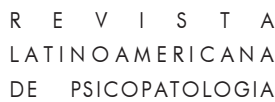

(Angstbereishaft) de uma "falta de gozo" localizada, que funciona como apelo ou como censura ao Outro. $\mathrm{O}$ objeto $a$ em posição de agência mestra é parceiro do sujeito esvaziado ou, melhor dizendo, de um curto-circuito do desejo sexual, engajando-o num sintoma que deixa como resto a angústia devastadora que Freud nomeou angústia (Automatischeangst). A "falta em gozar" comparece como gozo não localizado pelo significante paterno. Não se trata de apelo ao Nome-do-pai, nem de angústia diante da ameaça de castração. Deixo para uma outra oportunidade a tarefa de delimitar essa modalidade de angústia e os sintomas que se associam com ela explorando os dois complexos que segundo Lacan (1938) antecedem o complexo de Édipo: o desmame e a intrusão.

\section{Referências bibliográficas}

Coelho dos Santos, T. A angústia na teoria e na clínica psicanalítica. Revista do tempo psicanalítico, SPID/RJ, Rio de Janeiro, 1994, pp. 45-59.

. Da lógica da fantasia à finalidade do ato psicanalítico. Revista do tempo psicanalítico, SPID/RJ, Rio de Janeiro, 1995, pp. 155-65.

. O movimento psicanalítico e difusão da psicanálise. Revista do tempo psicanalítico, SPID/RJ, Rio de Janeiro, 1997, pp. 171-89.

. As estruturas freudianas da psicose: transferência e interpretação em casos borderline. Revista do tempo psicanalítico, SPID/RJ, Rio de Janeiro, 1998, pp. 149-73.

. As estruturas freudianas da psicose e sua reinvenção lacaniana. In Sobre a psicose. Rio de Janeiro: Contracapa, 1999a, pp. 45-75.

. Isso é uma estrutura significante: goza-se de um corpo. In Jimenez, S. e MotTA,

M. (orgs.). O desejo é o diabo: formaçães do inconsciente em Freud e Lacan. Rio de Janeiro: Contracapa, 1999b, pp. 149-63.

De que desejo do Outro a angústia é o sinal?. Latusa n. 4. Rio de Janeiro: Contracapa, 2000, pp. 173-97.

Dumont, L. (1983). Ensaios sobre o individualismo: uma perspectiva antropológica sobre a ideologia moderna. Publicações Dom Quixote, 1992.

Freud, S. (1912). Totem e tabu. E.S.B. Rio de Janeiro: Imago, 1979. v. XIV. (1920). Além do princípio do prazer. E.S.B. Op. cit.v. XVIII.

(1921). Psicologia de Massas e análise do ego. E. S.B. Op. cit. v. XVIII.

(1930[1929]). O mal-estar na civilização. E.S.B. Op. cit. v. XXI.

(1933[1932]). A questão de uma Weltanschauung psicanalítica. Novas conferên-

cias introdutórias. E.S.B. Op. cit. v. XXII.

GuidDEns, A. et alli. A modernização reflexiva. São Paulo: Unesp, 1995.

KumAR, K. Da sociedade pós-industrial à pós-moderna. Rio de Janeiro: Jorge Zahar, 1997.

LaCAN, J. (1938). Os complexos familiares. Rio de Janeiro: Jorge Zahar, 1984.

(1953). O mito individual do neurótico. Falo n. 1, Salvador, 1987.

Écrits. Paris: Seuil, 1966. 


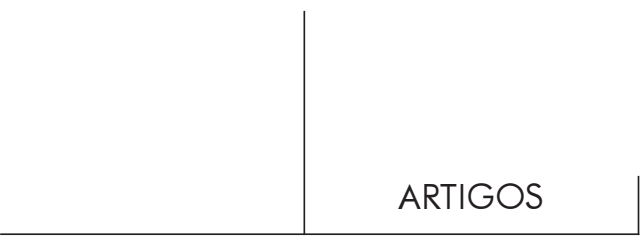

(1965). Kant avec Sade. In Écrits. Op. cit., pp. 765-92.

. La science et la verité. In Écrits. Op. cit., pp. 855-78.

(1969-1970). Le séminaire. Livre XVII. L'envers de la psychanalyse. Paris: Seuil, 1991.

(1972-1973). Le séminaire. Livre XX. Encore. Paris: Seuil, 1975.

(1974-1975). Le séminaire. Livre XXII. R.S.I. Inédito.

Laurent, E. et Miller, J.-A. (1996-1997). L'autre qui n'existe pas e ses comités d'éthique. Seminário inédito.

MARX, K. (1844). In Manuscritos econômicos filosóficos. Lisboa: Edições 70, 1975.

Miller, J.-A. El lenguage aparato del goce. Buenos Aires: Coleccion Diva, 2000a.

. Petite introduction à l'au-delá de l'Oedipe. In Document du travail sur la passe.

ECF, 1999, pp. 8-18.

- Les six paradigmes de la jouissance in La Cause Freudienne. Revue de

psychanalyse, publication de L'École de la Cause Freudienne, n. 43, pp. 7-31.

. La conversation d'Arcachon, in Collection Le Paon, Ed. Agalma, 1996.

\section{Resumos}

La psicoanálisis opera sobre el sujeto de la ciencia. El inconsciente no es lo que escapa a la ciencia, pero uno de los efectos del retorno de esa exclusión. El síntoma en la histeria a sido uno de esos efectos de retorno de la foraclusión del Nombre-delPadre por el discurso de la ciencia o de su reducción a la función del padre en la família y a las autoridades educativas y sociales. Actualmente, los analistas son confrontados con los nuevos síntomas que parecem tener su origem en el declinio progresivo de la función paterna. Ésos síntomas los obligan a resituar la transmisión de la castración más alla del padre. La inexistencia de la relación sexual o la división del objecto mujer/madre es una otra vertente de la castración que nos permite poner en foco la estructura del síntoma en la actualidad.

Palabras llave: Angústia, sintoma, función del padre, objecto $a$, castración

Le sujet sur lequel la psychanalyse opère est le sujet de la science. L'inconscient n'est pas ce qui échappe a la science mais un des effets de retour de cette exclusion. Le symptôme hysterique a eté un des effets de retour de la forclusion du Nom-du-père par le discours de la science où de sa réduction à la fonction de père de famille et a celle d'autorité educative et sociale. Aujourd'hui nous nous sommes confrontés a d'autres symptômes qui semblent originaires du videment progressif de la fonction paternelle et nous obligent a ressituer la transmission de la castration au delá du père. L' inexistence du rapport sexuel où la division de l'objet femme/mère est un autre version de la castration qui nous permet de cerner la structure du symptôme dans l'actualité.

Mots clés: Angoisse, symtome, fonction du père, objet a, castration 


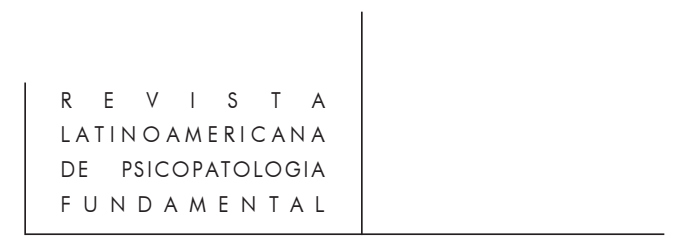

The subject on which psychoanalysis operates is the subject of science. The unconscious is not what escapes from science, but is rather one of the effects of this exclusion. Hysterical symptoms were among the effects of the return of forclusion of the name of the father by the discourse of science, or its reduction to the function of head of the family or the function of educational and social authority. Today we are faced with new symptoms that would seem to have their origin in the progressive decline of the father function. Following Freud, Lacan developed a new theory of castration, beyond the father, based on the role of the object divided between mother/woman in transmitting the castration complex.

Key words: Anxiety, symptom, father function, object a, castration

Versão inicial recebida em dezembro de 2000

Versão revisada recebida em fevereiro de 2001 